\title{
XRF Analysis of Heavy Metals for Surface Soil of Qarun Lake and Wadi El Rayan in Faiyum, Egypt
}

\author{
Samia M. El-Bahi ${ }^{1}$, Amany T. Sroor ${ }^{1}$, Najat F. Arhoma ${ }^{2}$, Saher M. Darwish ${ }^{2 *}$ \\ ${ }^{1}$ Nuclear Physics Laboratory, Faculty of Girls, Ain Shams University, Heliopolis, Egypt \\ ${ }^{2}$ Physics Department, Faculty of Science, Cairo University, Giza, Egypt \\ Email: *saherm2001@yahoo.com
}

Received April 22, 2013; revised May 25, 2013; accepted June 5, 2013

Copyright (c) 2013 Samia M. El-Bahi et al. This is an open access article distributed under the Creative Commons Attribution License, which permits unrestricted use, distribution, and reproduction in any medium, provided the original work is properly cited.

\begin{abstract}
The environmental pollution with some heavy metals for twenty four surface soil samples collected from Qarun Lake and Wadi El Rayan region in Faiyum, Egypt utilizing X-ray fluorescence (XRF) spectroscopy was measured. The concentrations of 13 elements $\mathrm{Cr}, \mathrm{Ni}, \mathrm{Cu}, \mathrm{Zn}, \mathrm{Zr}, \mathrm{Rb}, \mathrm{Y}, \mathrm{Ba}, \mathrm{Pb}, \mathrm{Sr}, \mathrm{Ga}, \mathrm{V}$ and $\mathrm{Nb}$ were determined. The elemental concentrations were compared with the normal values and other studies in different locations from the world. The correlation between elements appears that pollution inside the investigated lake and Wadi result from different sources of contamination present inside them. The results establish a database reference of radioactivity background levels around these regions.
\end{abstract}

Keywords: XRF; Heavy Metals; Surface Soil; Faiyum

\section{Introduction}

Studying the levels of radionuclide distribution in the environment provides essential radiological information [1-4]. As a result of rapid urbanization and industrial development, heavy metal contamination has been threatening human health [5]. A soil pollution assessment becomes very complex when different sources of contamination are present and their products are variably distributed. In these cases, the spatial variability of heavy metal concentrations in soils is basic information for identifying the possible sources of contamination and to delineate the strategies of site remediation.

The present study aims to assess the heavy metal contamination for surface soil of Qarun Lake and Wadi El Rayan regions in Faiyum, Egypt.

\section{Material and Methods}

Soil samples are collected from Qarun Lake and Wadi El Rayan in El Faiyum, middle Egypt, as shown in Figure 1. El Faiyum located $130 \mathrm{~km}$ southwest of Cairo. Qarun Lake is a closed saline lake, located in the deepest part of El Faiyum depression at the western desert, $70 \mathrm{~km}$ south Cairo-Egypt between longitudes $30^{\circ} 24^{\prime} \& 30^{\circ} 49^{\prime} \mathrm{E}$ and latitudes of $29^{\circ} 24^{\prime} \& 29^{\circ} 33^{\prime} \mathrm{N}$. It has an area of about

${ }^{*}$ Corresponding author.
$200 \mathrm{~km}^{2}$. It is used as a reservoir for the drainage water of El Faiyum province [6]. Qarun Lake water level is currently about $44 \mathrm{~m}$ below mean sea level [7]. The valley of Wadi El Rayan stretches on an area of $1759 \mathrm{~km}^{2}$. About $65 \mathrm{~km}$ southwest of El Faiyum city and $80 \mathrm{~km}$ west of the Nile River. The reserve is composed of: A $50.90 \mathrm{~km}^{2}$-upper lake, $62.00 \mathrm{~km}^{2}$-lower lake, waterfalls between the two lakes. Wadi El Rayan waterfalls considered to be the largest waterfalls in Egypt. This region suffers from complex problems of pollution as a result of the high salinity in the water and presence of sewage, agricultural drainage flows inside it [8].

Twenty four surface soil samples, twelve from Qarun Lake $\left(\mathrm{Q}_{1}\right.$ to $\left.\mathrm{Q}_{12}\right)$ and Twelve from Wadi El Rayan ( $\mathrm{W}_{1}$ to $\mathrm{W}_{12}$ ), were collected from different locations along 12 kilometer, where the distance between each successive samples about one kilometer. The soil samples were dried, homogenized and sieved at 200 mesh grain size, pressed powder pellets were prepared by filling an alumina cup, (diameter $4 \mathrm{~cm}$, height $1.2 \mathrm{~cm}$ and weight $3 \mathrm{gm}$ ), with 9 gm of crystalline boric acid covered by $1 \mathrm{gm}$ of the grounded sample, and then pressed under 12 tons by using semi-automatic hydraulic press model HERZOG HTP-40. To avoid trace elements contaminations, the powdered samples were subjected to complete chemical analysis in the laboratories of Nuclear Materials Authority, Cairo 


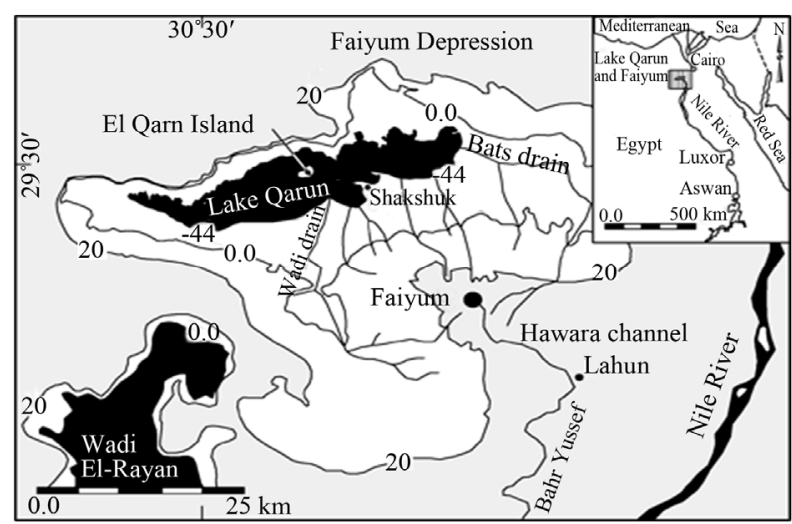

Figure 1. Map of the geology of Faiyum indicating location of Qarun Lake, Wadi El-Rayan and the Faiyum depression, showing elevations in meters w.r.t. mean sea level.

Egypt, using the wet chemical analyses for the major oxides and XRD to analyze the trace elements.

Trace elemental analysis of samples by X-Ray fluorescence were performed using a Philips PW X-Unique II X-ray spectrometer with automatic sample changer PW 1510, (30 positions) at the Nuclear Materials Authority, Cairo, Egypt. This instrument is connected to a computer system using X-40 program for spectrometry. The trace elements concentrations are calculated from the program's calibration curves which were set up according to international reference materials, (standards), as NIM-G, G-2, GSP-1, AGV-1, JB-1 and NIM-D. The trace elements were measured by calibrating the system under the conditions of Rh-target tube, LiF-420 crystal, gas flow proportional counter, (GFPC), coarse collimators, vacuum, $30 \mathrm{kV}$ and $40 \mathrm{~mA}$ for the determination of $\mathrm{V}, \mathrm{Cr}, \mathrm{Co}, \mathrm{Ni}, \mathrm{Cu}, \mathrm{Zn}$ and $\mathrm{Ga}, 70 \mathrm{kV}$ and $15 \mathrm{~mA}$, for Rb, $\mathrm{Sr}, \mathrm{Y}, \mathrm{Zr}$ and $\mathrm{Nb}$ and $100 \mathrm{kV}$ and $10 \mathrm{~mA}$ for the determination of $\mathrm{Ba}$ and $\mathrm{Pb}$. The detection limit is the lowest concentration, and it is function of the level of background noise relative to an element signal [9]. The detection limit for the elements measured by XRF technique is estimated at $2 \mathrm{ppm}$ for $\mathrm{Rb}, \mathrm{Nb}, \mathrm{Ga}, \mathrm{Co}, \mathrm{Y}$ and $\mathrm{Sr}$ and at 8 $\mathrm{ppm}$ for $\mathrm{Pb}$ and $\mathrm{Cu}$ and $5 \mathrm{ppm}$ for other measured trace elements.

\section{Results and Discussion}

XRF results for collected surface soil samples from Qarun Lake and Wadi El Rayan regions evident the existence of the following elements: $\mathrm{Cr}, \mathrm{Ni}, \mathrm{Cu}, \mathrm{Zn}, \mathrm{Zr}, \mathrm{Rb}$, $\mathrm{Y}, \mathrm{Ba}, \mathrm{Pb}, \mathrm{Sr}, \mathrm{Ga}, \mathrm{V}$ and $\mathrm{Nb}$, shown in Table 1. It can be seen that $\mathrm{Cr}$ and $\mathrm{Cu}$ concentrations for all studied sites are greater than the normal values 30 and $20 \mathrm{mg} / \mathrm{kg}$, respectively, while the $\mathrm{Ni}, \mathrm{Zn}, \mathrm{Pb}$ and $\mathrm{V}$ concentrations are lower than the normal values 20,100, 20 and 50, respectively [10] for all studied sites except site $Q_{5}$ at Qarun Lake recorded high concentrations for $\mathrm{Ni}$ and $\mathrm{V}$. It is clear also that, samples have high concentration of $\mathrm{Zr}$ and $\mathrm{Nb}$ which means a presence of uranium and thorium in these samples. Also Sr has a great importance, since ${ }^{90} \mathrm{Sr}$ is a radioactive isotope with a half-life of 28.78 years. Table 1 also shows that, all samples contain a high concentration of Ba which can be separated using different methods in order to use it in different important industries [11]. Barium sulfate is important to the petroleum industry. Barium oxide is used in a coating of the electrodes of fluorescent lamps. Barium carbonate is used in glass-making. Barium fluoride is used for optics in infrared applications. Barium, commonly as barium nitrate, is used to give green colors in fireworks. Also, there are other trace elements like $\mathrm{Rb}, \mathrm{Y}$ and $\mathrm{Ga}$ with different concentrations. A soil pollution assessment becomes very complex when different sources of contamination are present and their products are variably distributed [12].

Table 2 gives the comparison of trace element concentrations in present work with other reference data [10, 12-16]. It can be seen that the present concentrations of $\mathrm{Cr}, \mathrm{Ni}, \mathrm{Cu}, \mathrm{Zn}$ and $\mathrm{Pb}$ is lower than that (ISIW) in Romania [10] and Hyderabad city in India [15] and all these concentrations exceeded threshold values [16]. Table 2 shows also that the present concentration of $\mathrm{V}$ is lower than that of (ISIW) at Romania and the threshold value [16]. Existences of all these elements with different values caused many diseases if reached to human bodies [17]. For example, Cr caused carcinoma, $\mathrm{Cu}$ caused cirrhosis, nausea, vomiting and diarrhea, Ba high toxic substantive caused carcinoma, hypogonadism and diarrhea.

Using the elemental analysis data obtained (Table 1), we have calculated the matrices shown in Tables $\mathbf{3}$ and $\mathbf{4}$, by calculating the Pearson's correlation coefficient $R^{2}$ [18] between each two elements in soils collected from Qarun Lake and Wadi El Rayan, respectively.

From the correlation matrix of Qarun Lake (Table 3), it can be seen that the Pearson coefficient $R^{2}$ has greater values than 0.60 for the following pairs of elements: Ba-Pb, Ba-Rb, Ba-V, Ba-Ni, Cr-Nb, Cr-Sr, Cr-Y, Ni-Rb, $\mathrm{Ni}-\mathrm{Pb}, \mathrm{Ni}-\mathrm{V}$, Ni-Zn, Rb-Pb, Rb-V, V-Pb, Y-Sr, Zn-Ba, $\mathrm{Zn}-\mathrm{Pb}, \mathrm{Zn}-\mathrm{Rb}$ and $\mathrm{Zn}-\mathrm{V}$. The correlation matrix of Wadi El Rayan samples (Table 4) shows that the Pearson coefficient $R^{2}$ has greater values than 0.60 for the following pairs of elements: Ba-V, Ba-Y, Ba-Zr, Zr-Cu, Zr-V and $\mathrm{Zr}-\mathrm{Y}$. This means that all elements that make an Rsquared value greater than 0.60 with another element will co-precipitate, to some extent, with that element. This relationship for a few selected elements in Table 4, proofs also that the pollution inside it is caused by different sources of contamination.

\section{Conclusion}

XRF technique has been employed in order to reveal their mineral composition to evaluate the pollution of soil 
Table 1. Trace elements concentrations (in ppm) using XRF spectroscopy for surface soil samples from Qarun Lake and Wadi El Rayan in Faiyum, Egypt.

\begin{tabular}{|c|c|c|c|c|c|c|c|c|c|c|c|c|c|}
\hline Sample & $\mathrm{Cr}$ & $\mathrm{Ni}$ & $\mathrm{Cu}$ & $\mathrm{Zn}$ & $\mathrm{Zr}$ & $\mathrm{Rb}$ & $\mathrm{Y}$ & $\mathrm{Ba}$ & $\mathrm{Pb}$ & $\mathrm{Sr}$ & Ga & $\mathrm{V}$ & $\mathrm{Nb}$ \\
\hline Q1 & 98 & 12 & 43 & 44 & $79^{*}$ & 26 & 11 & 103 & u.d & 33 & 12 & 11 & 31 \\
\hline Q2 & 52 & 11 & 37 & 28 & 141 & $16^{*}$ & 22 & 96 & u.d & 71 & 11 & $7^{*}$ & 24 \\
\hline Q3 & 82 & 16 & 46 & 29 & 146 & 26 & 18 & 236 & u.d & 57 & 12 & 17 & 28 \\
\hline Q4 & 86 & 23 & 46 & 36 & 150 & 27 & 17 & 395 & 6 & 56 & $17^{* *}$ & 31 & $33^{* *}$ \\
\hline Q5 & 62 & $46^{* *}$ & 43 & $90^{* *}$ & 168 & $51^{* *}$ & 19 & $725^{* *}$ & $17^{* *}$ & 61 & $10^{*}$ & $57^{* *}$ & 28 \\
\hline Q6 & 48 & 17 & 46 & 27 & 146 & $16^{*}$ & 22 & 153 & u.d & 70 & 11 & 15 & $22^{*}$ \\
\hline Q7 & 26 & $9^{*}$ & $34^{*}$ & 32 & 152 & 17 & 26 & $57^{*}$ & u.d & 82 & $10^{*}$ & $7^{*}$ & 23 \\
\hline Q8 & 32 & 14 & 39 & $25^{*}$ & 129 & 17 & 21 & 63 & u.d $\mathrm{d}^{*}$ & 67 & 11 & $7^{*}$ & 24 \\
\hline Q9 & 29 & 13 & 37 & 32 & 166 & 19 & 26 & 166 & 4 & 84 & $10^{*}$ & 14 & 23 \\
\hline Q10 & 34 & 12 & 35 & 28 & 149 & 17 & 34 & 144 & u.d & 75 & 11 & 11 & 24 \\
\hline Q11 & 44 & 23 & 43 & 49 & 231 & 39 & 27 & 529 & 6 & 85 & $10^{*}$ & 40 & 25 \\
\hline Q12 & 56 & 15 & 40 & 37 & 182 & 27 & 26 & 302 & u.d & 80 & 11 & 21 & 25 \\
\hline W1 & $23^{*}$ & 18 & $52^{* *}$ & 28 & 98 & 20 & $9^{*}$ & 155 & u. $\mathrm{d}^{*}$ & 26 & 11 & 11 & 28 \\
\hline W2 & 203 & 15 & 48 & 33 & 252 & 22 & 24 & 285 & 2 & 69 & 11 & 12 & 27 \\
\hline W3 & 157 & 14 & 49 & 28 & 194 & 20 & 19 & 223 & u. $\mathrm{d}^{*}$ & 59 & 12 & 12 & 28 \\
\hline W4 & 180 & 16 & 43 & 28 & 420 & 19 & 11 & 200 & u. $d^{*}$ & 34 & 12 & 14 & 30 \\
\hline W5 & 192 & 17 & 50 & 30 & 320 & 22 & 15 & 250 & u.d $\mathrm{d}^{*}$ & 100 & 11 & 14 & 29 \\
\hline W6 & 175 & 14 & 47 & 29 & 203 & 23 & 14 & 270 & 2 & 120 & 13 & 16 & 31 \\
\hline W7 & 160 & 17 & 46 & 32 & 554 & 24 & 35 & 302 & 2 & $17^{*}$ & 12 & 16 & 28 \\
\hline W8 & $203^{* *}$ & 15 & 49 & 27 & 168 & 18 & 16 & 193 & u. $\mathrm{d}^{*}$ & 49 & 12 & 11 & 29 \\
\hline W9 & 145 & 15 & 48 & 31 & 118 & 25 & 11 & 251 & u.d $\mathrm{d}^{*}$ & 35 & 13 & 13 & 32 \\
\hline W10 & 194 & 14 & 48 & 32 & 260 & 20 & 20 & 291 & u.d $\mathrm{d}^{*}$ & 78 & 12 & 15 & 31 \\
\hline W11 & 123 & 15 & 43 & 30 & $737^{* *}$ & 21 & $38^{* *}$ & 433 & 2 & $137^{* *}$ & 11 & 17 & 27 \\
\hline W12 & 121 & 16 & 43 & 30 & 730 & 20 & 36 & 433 & 2 & $137^{* *}$ & 12 & 17 & 30 \\
\hline
\end{tabular}

*The lowest value; ${ }^{* *}$ The highest value.

Table 2. Comparison of the trace element concentrations (in ppm) for studied samples with other studies in different locations from the world.

\begin{tabular}{|c|c|c|c|c|c|c|c|c|}
\hline Element & Karon Lake* & Wadi El Rayan* & $\begin{array}{c}\text { Marmara Sea } \\
{[12]}\end{array}$ & $\begin{array}{c}\text { Gulf of Naples } \\
\text { [13] }\end{array}$ & Saros Gulf [14] & $\begin{array}{c}\text { (ISIW) at Romania } \\
{[10]}\end{array}$ & $\begin{array}{l}\text { Hyderabad, } \\
\text { India [15] }\end{array}$ & $\begin{array}{c}\text { Threshold value } \\
\text { [16] }\end{array}$ \\
\hline $\mathrm{Cr}$ & $26-98$ & $23-203$ & $65-85$ & $11-66$ & $35-75$ & $52.9-101.3$ & $12.3-480.6$ & $10-50$ \\
\hline $\mathrm{Ni}$ & $9-46$ & $14-18$ & $35-50$ & $0.01-26.7$ & $<5-75$ & $41.9-65.6$ & $12.6-132.0$ & $10-50$ \\
\hline $\mathrm{Cu}$ & $34-46$ & $43-52$ & $20-80$ & $3-664$ & $<0.5-48$ & $<15-52.8$ & 11.1 - 186.6 & $10-40$ \\
\hline $\mathrm{Zn}$ & $25-90$ & $27-33$ & $60-145$ & $77-1765$ & $25-120$ & $34.0-121.0$ & $40.8-882.2$ & $20-200$ \\
\hline $\mathrm{Zr}$ & $79-231$ & $98-737$ & & & & & & - \\
\hline $\mathrm{Rb}$ & $16-51$ & $18-25$ & & & & & & - \\
\hline $\mathrm{Y}$ & $11-34$ & $9-38$ & & & & & & - \\
\hline $\mathrm{Ba}$ & $57-725$ & $155-433$ & & & & & & $100-1000$ \\
\hline $\mathrm{Pb}$ & u.d - 17 & u.d - 2 & & & & $11.0-52.2$ & $42.9-1832.5$ & $10-30$ \\
\hline $\mathrm{Sr}$ & $33-85$ & $17-137$ & & & & & & - \\
\hline $\mathrm{Ga}$ & $10-17$ & $11-13$ & & & & & & - \\
\hline V & $7-57$ & $11-17$ & & & & $95.5-110.7$ & & $30-150$ \\
\hline $\mathrm{Nb}$ & $22-33$ & $27-32$ & & & & & & - \\
\hline
\end{tabular}

*Present study. 
Table 3. Correlation coefficent between trace elements in Qarun Lake, Egypt.

\begin{tabular}{|c|c|c|c|c|c|c|c|c|c|c|c|c|c|}
\hline Element & $\mathrm{Cr}$ & $\mathrm{Ni}$ & $\mathrm{Cu}$ & $\mathrm{Zn}$ & $\mathrm{Zr}$ & $\mathrm{Rb}$ & Y & $\mathrm{Ba}$ & $\mathrm{Pb}$ & $\mathrm{Sr}$ & $\mathrm{Ga}$ & V & $\mathrm{Nb}$ \\
\hline $\mathrm{Cr}$ & 1 & & & & & & & & & & & & \\
\hline $\mathrm{Ni}$ & 0.06 & 1 & & & & & & & & & & & \\
\hline $\mathrm{Cu}$ & 0.52 & 0.21 & 1 & & & & & & & & & & \\
\hline $\mathrm{Zn}$ & 0.06 & $0.81^{*}$ & 0.05 & 1 & & & & & & & & & \\
\hline $\mathrm{Zr}$ & 0.17 & 0.12 & 0 & 0.06 & 1 & & & & & & & & \\
\hline $\mathrm{Rb}$ & 0.12 & $0.79^{*}$ & 0.19 & $0.86^{*}$ & 0.18 & 1 & & & & & & & \\
\hline $\mathrm{Y}$ & $0.65^{*}$ & 0.05 & 0.4 & 0.06 & 0.34 & 0.06 & 1 & & & & & & \\
\hline $\mathrm{Ba}$ & 0.06 & $0.85^{*}$ & 0.22 & $0.72^{*}$ & 0.35 & $0.89^{*}$ & 0.01 & 1 & & & & & \\
\hline $\mathrm{Pb}$ & 0.02 & $0.9^{*}$ & 0.08 & $0.83^{*}$ & 0.14 & $0.74^{*}$ & 0.02 & $0.79^{*}$ & 1 & & & & \\
\hline $\mathrm{Sr}$ & $0.73^{*}$ & 0.02 & 0.28 & 0.04 & 0.57 & 0.03 & $0.74^{*}$ & 0 & 0.002 & 1 & & & \\
\hline $\mathrm{Ga}$ & 0.39 & 0.001 & 0.24 & 0.03 & 0.08 & 0.003 & 0.2 & 0.003 & 0.0003 & 0.25 & 1 & & \\
\hline V & 0.06 & $0.89^{*}$ & 0.23 & $0.76^{*}$ & 0.29 & $0.89^{*}$ & 0.01 & $0.99^{*}$ & $0.84^{*}$ & 0.001 & 0.003 & 1 & \\
\hline $\mathrm{Nb}$ & $0.78^{*}$ & 0.13 & 0.33 & 0.12 & 0.09 & 0.21 & 0.49 & 0.14 & 0.11 & 0.59 & 0.57 & 0.15 & 1 \\
\hline
\end{tabular}

*Strong correlation.

Table 4. Correlation coefficent between trace elements in Wadi El Rayan, Egypt.

\begin{tabular}{|c|c|c|c|c|c|c|c|c|c|c|c|c|c|}
\hline Element & $\mathrm{Cr}$ & $\mathrm{Ni}$ & $\mathrm{Cu}$ & $\mathrm{Zn}$ & $\mathrm{Zr}$ & $\mathrm{Rb}$ & $\mathrm{Y}$ & $\mathrm{Ba}$ & $\mathrm{Pb}$ & $\mathrm{Sr}$ & $\mathrm{Ga}$ & V & $\mathrm{Nb}$ \\
\hline $\mathrm{Cr}$ & 1 & & & & & & & & & & & & \\
\hline $\mathrm{Ni}$ & 0.28 & 1 & & & & & & & & & & & \\
\hline $\mathrm{Cu}$ & 0.02 & 0.03 & 1 & & & & & & & & & & \\
\hline $\mathrm{Zn}$ & 0.07 & 0.01 & 0.02 & 1 & & & & & & & & & \\
\hline $\mathrm{Zr}$ & 0.004 & 0.02 & $0.69^{*}$ & 0.05 & 1 & & & & & & & & \\
\hline $\mathrm{Rb}$ & 0.001 & 0.001 & 0.002 & 0.37 & 0.001 & 1 & & & & & & & \\
\hline Y & 0.0001 & 0.0004 & 0.37 & 0.19 & $0.74^{*}$ & 0.008 & 1 & & & & & & \\
\hline $\mathrm{Ba}$ & 0 & 0.03 & 0.49 & 0.22 & $0.71^{*}$ & 0.03 & $0.76^{*}$ & 1 & & & & & \\
\hline $\mathrm{Pb}$ & 0 & 0.01 & 0.29 & 0.20 & 0.38 & 0.12 & 0.56 & 0.53 & 1 & & & & \\
\hline $\mathrm{Sr}$ & 0.01 & 0.12 & 0.17 & 0.01 & 0.26 & 0.004 & 0.21 & 0.54 & 0.25 & 1 & & & \\
\hline $\mathrm{Ga}$ & 0.05 & 0.23 & 0.03 & 0.01 & 0.05 & 0.12 & 0.06 & 0.01 & 0.002 & 0.01 & 1 & & \\
\hline $\mathrm{V}$ & 0.002 & 0.01 & 0.56 & 0.12 & $0.64^{*}$ & 0.08 & 0.44 & $0.67^{*}$ & 0.41 & 0.39 & 0.03 & 1 & \\
\hline $\mathrm{Nb}$ & 0.03 & 0.09 & 0.004 & 0.0004 & 0.07 & 0.04 & 0.18 & 0.01 & 0.09 & 0.0004 & $0.64^{*}$ & 0.03 & 1 \\
\hline
\end{tabular}

*Strong correlation.

with heavy metals. The concentrations of thirteen elements (Cr, Ni, Cu, Zn, Zr, Rb, Y, Ba, Pb, Sr, Ga, V and $\mathrm{Nb}$ ) in Qarun Lake and Wadi El Rayan regions were determined. A soil pollution assessment becomes very complex when different sources of contamination are present and their products are variably distributed with time assembling and become toxic. As a result of existent of all these elements, these places are pollutant and when using it in agriculture will cause danger to humans, since toxic substances will move toxic substances from soil into plants and then to human bodies. Therefore, we recommend not use it in agriculture, until solving the main problems of pollution in this region, such as high salinity in water and presence of sewage, agricultural drainage flows inside it and others. The results of this study can be used as a data baseline for preparing a radiological map of the study area, especially at the chosen sites.

\section{REFERENCES}

[1] A. S. Alaamer, "Assessment of Human Exposures to Natural Sources of Radiation in Soil of Riyadh, Saudi Arabia,” Turkish Journal Engineering Environmental Sciences, Vol. 32, No. 4, 2008, pp. 229-234.

[2] N. N. Jibiri and G. O. Adewuyi, "Radionuclide Contents and Physico-Chemical Characterization of Solid Waste and Effluent Samples of Some Selected Industries in the City of Lagos, Nigeria,” Radioprotection, Vol. 43, No. 2, 2008, pp. 203-212. doi:10.1051/radiopro:2007053 
[3] B. Palumbo, M. Angelone and A. Bellanca, "Influence of Inheritance and Pedogenesis on Heavy Metal Distribution in Soils of Sicily, Italy,” Geoderma, Vol. 95, No. 3, 2000, pp. 247-266. doi:10.1016/S0016-7061(99)00090-7

[4] UNSCEAR, "Sources, Effect and Risk of Ionizing Radiation,” United Nations, New York, 2000.

[5] V. Salonen and K. Korkka-Niemi, "Influence of Parent Sediments on the Concentration of Heavy Metals in Urban and Suburban Soils in Turku," Finland Applied Eochemistry, Vol. 22, No. 5, 2007, pp. 906-918.

[6] A. A. A. Mageed, "Effect of Some Environmental Factors on the Biodiversity of Holozooplankton Community in Lake Qarun, Egypt,” Egyptian Journal of Aquatic Research, Vol. 31, No. 2, 2005, pp. 230-234.

[7] A. H. Meshal, "The Problem of the Salinity Increase in Lake Qarun (Egypt) and a Propose Solution,” Journal Conceal International Pour l'Exploration de la Mer, Vol. 37, No. 2, 1977, pp. 137-143.

[8] P. J. Mehringer, K. L. Petersen and F. A. Hassan, “A Pollen Record from Birket Qarun and the Recent History of the Fayum, Egypt," Quaternary Research, Vol. 11, No. 2, 1979, pp. 238-256. doi:10.1016/0033-5894(79)90006-1

[9] K. Norrish and B. W. Chappell, "X-Ray Fluorescence Spectrography,” In: J. Zussman, Ed., Physical Methods of Determinative Minerology, Academic press, New York, 1966, pp. 161-214.

[10] E. Antoaneta, A. Bosneaga and L. Georgescu, "Determination of Heavy Metals in Soils Using XRF Technique," Romanian Journal of Physics, Vol. 55, No. 7-8, 2009, pp. 815-820.

[11] J. Emsley, “Nature’s Building Blocks,” Oxford University Press, Oxford, 2001, pp. 506-510.

[12] S. Akyuz, T. Akyuz, A. O. Algan, N. M. Mukhamedshina and A. A. Mirsagatova, "Energy Dispersive X-Ray Fluorescence and Neutron Activation Analysis of Surficial Sediments of the Sea of Marmara and the Black Sea around Istanbul,” Journal Radioanalytical and Nuclear Chemistry, Vol. 254, No. 8, 2002, pp. 569-575. doi:10.1023/A:1021606608862

[13] E. Romano, A. Ausili, N. Zharova, M. C. Mango, B. Pavoni and M. Gabellini, "Marine Sediment Concentration of an Industrial Site at Port of Bagnoli, Gulf of Naples, Southern Italy,” Marine Pollution Bulletin, Vol. 49, No. 5, 2004, pp. 487-495. doi:10.1016/j.marpolbul.2004.03.014

[14] T. Akyuz, N. Mukhamedshina, S. Akyuz, E. Sari and A. A. Mirsagatova, "Toxic and Trace Element Analysis of Surface Sediments from theGulf of Saros by INAA and XRF methods," Radioanalytical and Nuclear Chemistry, Vol. 273, No. 3, 2007, pp. 747-751. doi:10.1007/s10967-007-0941-3

[15] N. N. Vandana Partha, Murthya and P. R. Saxena, “Assessment of Heavy Metal Contamination in Soil around Hazardous Waste Disposal Sites in Hyderabad City (India) Natural and Anthropogenic Implications,” Environmental Research and Management, Vol. 2, No. 1, 2011, pp. 2734.

[16] D. C. Adriano, "Trace Elements in Terrestrial Environments," Biogeochemistry, Bioavailability, and Risks of Metals, 2nd Edition, Springer Verlag, New York, 2001.

[17] S. Martin and W. Griswold, "Human Health Effects of Heavy Metals," Center for Hazardous Substance Research, Kansas State University, 2009. www.engg.ksu.edu/CHSR/

[18] H. Lohninger, “Teach/Me-Data Analysis,” Springer-Verlag, New York, 1999. 